\title{
PENGARUH PERPUTARAN AKTIVA TETAP, PERPUTARAN PERSEDIAAN, DAN PERPUTARAN PIUTANG TERHADAP ECONOMIC PERFORMANCE
}

\author{
Daniel Rahandri ${ }^{1}$
}

Universitas Muhammadiyah Tangerang

drahandri@gmail.com

\begin{abstract}
The purpose of this study was to determine the effect of fixed assets turnover, inventory turnover, and accounts receivable turnover on economic performance in manufacturing companies listed on the Indonesia Stock Exchange (IDX). The periode time of the research is 5 years that is periode 2014 -2018 Population of this study includes all manufacturing companies listed on the Indonesia Stock Exchange (IDX) for the 2014-2018 period. Data collection method used was technique purposing sampling. The results showed that the rotation of fixed assets had no effect on economic performance. While inventory turnover and accounts receivable turnover affect the economic performance. and the turnover of fixed assets, inventory turnover, and accounts receivable turnover together affect the economic performance.
\end{abstract}

Keywords : Economic Performance, Fixed Assets Turnover, Inventory Turnover, Accounts Receivable Turnover 


\section{PENDAHULUAN}

Setiap perusahaan yang didirikan dalam menjalankan kegiatan usahanya tidak terlepas dari tujuan utamanya, yaitu untuk memperoleh laba atau keuntungan semaksimal mungkin dan membuat perusahaan hidup dalam jangka panjang. Dalam era globalisasi seperti saat ini, munculnya kompetitor-kompetitor baru di berbagai sektor industri perusahaan membuat persaingan bisnis dari tahun ke tahun menjadi sangat ketat. Fenomena ekonomi yang terjadi ini menuntut setiap manajemen di perusahaan untuk berusaha melaksanakan strategi yang tepat. Berbagai strategi yang dijalankan seperti melakukan manajemen yang maksimal dan melakukan kebijakan-kebijakan terbaik dalam mengelola kinerja bisnis mereka agar semakin siap diri dalam bersaing, berkembang, dan perusahaan dapat mempertahankan kelangsungan hidupnya. (Suprihatin \& Nasser, 2016)

Pengukuran kinerja merupakan salah satu faktor yang sangat penting bagi perusahaan, karena pengukuran tersebut dapat mempengaruhi perilaku pengambilan keputusan dalam perusahaan. Pengukuran kinerja keuangan perusahaan bergantung pada sudut pandang yang diambil dan tujuan analisis. Oleh sebab itu, manajemen perusahaan perlu menyesuaikan kondisi perusahaan dengan alat ukur penilaian kinerja serta tujuan dari pengukuran kinerja keuangan perusahaan itu sendiri, sehingga dapat tercapai tujuan perusahaan. (Winata, Yuniarta, \& Sinarwati, 2016)

Kinerja ekonomi perusahaan tidak hanya dilihat dari seberapa besar perusahaan dalam menghasilkan laba, tetapi juga dilihat dari kemampuan perusahaan dalam memaksimumkan kemakmurkan pemegang saham (stakeholder).

Kinerja ekonomi perusahaan dapat dipengaruhi oleh banyak faktor. Salah satu faktor yang mempengaruhi kinerja ekonomi perusahaan adalah efisiensi. Efisiensi tidak hanya bisa dilihat dari seberapa besar perusahaan dapat menekan beban operasional perusahaan, tetapi juga efisiensi perusahaan dalam menggunakan sumber daya secara optimal.

Rasio aktivitas melihat seberapa besar efisiensi penggunaan aset oleh perusahaan. Rasio ini melihat seberapa besar dana tertanam pada aset perusahaan. Jika dana yang tertanam pada aset tertentu cukup besar, sementara dana tersebut mestinya bisa dipakai untuk investasi pada aset lain yang lebih produktif, maka profitabilitas perusahaan tidak sebaik yang seharusnya. (Hanafi, 2016)

Perputaran aktiva tetap, adalah rasio antara penjualan dengan aktiva tetap neto. Rasio ini menunjukan bagaimana perusahaan menggunakan aktiva tetapnya seperti gedung, kendaraan, mesin-mesin, perlengkapan kantor (Sartono, 2016). Semakin tinggi angka perputaran aktiva tetap, semakin efektif perusahaan mengelola asetnya. Rasio perputaran aktiva tetap menunjukkan sejauh mana kemampuan perusahaan menghasilkan penjualan berdasarkan aktiva tetap yang dimiliki oleh perusahaan. (Hanafi, 2016)

Persediaan merupakan elemen penting dalam perusahaan karena pada umumnya jumlah modal kerja yang tertanam dalam persediaan cukup besar. Oleh karena itu jumlah persediaan dalam perusahaan harus diatur dan dikendalikan sedemikian rupa sesuai dengan kebutuhan dan 
kegiatan operasi yang dilakukan perusahaan sehingga jumlah persediaan tersebut tidak terlalu besar ataupun terlalu kecil. Persediaan yang terlalu besar akan merugikan perusahaan karena akan menimbulkan penumpukan dana atau investasi yang berlebihan, jumlah persediaan yang besar dapat menjadikan resiko yang juga besar dalam hal biaya dan penanganan persediaan tersebut. Persediaan dalam jumlah yang berlebihan akan meningkatkan biayabiaya, seperti biaya penyimpanan (biaya gudang), pengamanan, asuransi, dan pajak properti serta beban-beban terkait lainnya. Dan juga, persediaan yang berlebihan dapat meningkatkan resiko kerugian akibat penurunan harga, penurunan kualitas, kerusakan, atau perubahan pola belanja pelanggan dan bahkan persediaan dapat menjadi tidak terpakai. Sebaliknya jumlah persediaan yang terlalu kecil di dalam gudang akan mengganggu kelancaran dan menghambat aktivitas perusahaan. Misalnya, perusahaan akan kekurangan atau kehabisan persediaan sehingga perusahaan tidak dapat memenuhi permintaan pelanggannya, hal ini dapat menyebabkan perusahaan kehilangan penjualan dan kehilangan kepercayaan pelanggan. Secara umum, semakin cepat perputaran persediaan, semakin efisien dan efektif perusahaan mengelolah persediaannya untuk mencapai suatu tingkat profitabilitas tertentu yang diperoleh dari penggunaan persediaan untuk menghasilkan penjualan. (Lestiowati, 2018)

Kebijakan penjualan secara kredit merupakan salah satu upaya perusahaan untuk memperoleh penjualan yang dapat menghasilkan pendapatan bagi perusahaan. Karena adanya penjualan secara kredit ini, maka timbul piutang. Besarnya piutang pada perusahaan dipengaruhi oleh jumlah penjualan kredit yang dilakukan perusahaan dan jangka waktu kredit yang diberikan. Penjualan secara kredit memungkinkan pelanggan yang tidak dapat membeli secara tunai dapat membeli barang yang dibutuhkan. Akan tetapi, kebijakan penjualan secara kredit ini juga dapat memungkinkan perusahaan menanggung resiko kerugian sebagian akibat dari piutang yang tidak tertagih. Oleh karena itu, perusahaan harus mampu mengendalikan piutangnya agar penjualan yang tinggi dapat dihasilkan tanpa disertai pertumbuhan yang juga tinggi pada piutang sehingga pendapatan perusahaan yang diperoleh dari penjualan tersebut meningkat. (Lestiowati, 2018)

\section{KAJIAN PUSTAKA DAN PENGEMBANGAN HIPOTESIS Teori Keagenan}

Jensen dan Meckling (1976) menyatakan hubungan keagenan muncul ketika satu atau lebih individu (pengusaha) membayar individu lain (agen atau karyawan) untuk bertindak atas namanya, mendelegasikan kekuatan untuk membuat keputusan kepada agen dan karyawan. Dalam konteks manajemen keuangan, hubungan ini muncul antara: pemegang saham dengan manajer dan pemegang saham dengan kreditor (pemegang obligasi). Kontrol perusahaan saat ini sering diserahkan kepada manajer profesional yang bukan pemilik perusahaan. Pemilik tidak lagi dapat mengendalikan perusahaan, karena semakin besar dan kompleks. Tujuan utama yang ingin dicapai adalah memaksimalkan 
kemakmuran pemilik perusahaan. Dengan demikian manajemen dapat dilihat sebagai agen dari pemilik perusahaan yang mempekerjakan mereka, memberikan kekuatan dan wewenang untuk mengambil keputusan terbaik yang menguntungkan perusahaan. (Sarita, Takdir, Sujono, \& Sabrin, 2016)

\section{Teori Sinyal}

Isyarat atau sinyal menurut Brigham dan Houston (2001) adalah tindakan yang diambil oleh manajemen perusahaan untuk memberikan panduan kepada investor tentang cara melihat prospek manajemen perusahaan. Menurut Brigham dan Houston (2001), perusahaan dengan prospek yang menguntungkan akan mencoba untuk menghindari penjualan saham dan melakukan modal baru yang diperlukan dengan cara lain, termasuk penggunaan hutang yang melebihi target struktur modal normal. Perusahaan dengan prospek yang kurang menguntungkan cenderung menjual sahamnya. Pengumuman penerbitan saham oleh suatu perusahaan biasanya merupakan isyarat (sinyal) bahwa manajemen prospek perusahaan tampak suram. Jika sebuah perusahaan menawarkan penjualan saham baru lebih sering dari biasanya, harga saham akan turun, karena menerbitkan saham baru berarti memberikan isyarat negatif yang kemudian dapat menekan harga saham prospek perusahaan bahkan lebih cerah. Untuk memasuki beberapa pasar yang ia perdagangkan, ia harus meminjam lagi sejumlah besar uang untuk membeli infrastruktur yang dibutuhkan untuk mengangkut, menyimpan, dan mengirimkan komoditas yang diperdagangkan.
Tingginya tingkat hutang menyebabkan jalan terbuka yang luas dari kebangkrutan dan juga menurunkan investasi dan juga akan membuat bank menarik kembali pinjamannya. (Sarita et al., 2016)

\section{Kinerja Keuangan (Economic Performace)}

Kinerja adalah kemampuan kerja yang ditunjukkan dengan hasil kerja. Kinerja perusahaan merupakan sesuatu yang dihasilkan oleh suatu perusahaan dalam periode tertentu dengan mengacu pada standar yang ditetapkan. Kinerja perusahaan hendaknya merupakan hasil yang dapat diukur dan menggambarkan kondisi empirik suatu perusahaan dari berbagai ukuran yang disepakati. Untuk mengetahui kinerja yang dicapai maka dilakukan penilaian kinerja. (Mustoffa, 2014)

Menurut G. Sugiyarso dan F. Winarni (2006,111) dalam (Achmad, 2013) kinerja dapat diartikan sebagai "tingkat pencapaian hasil atau tujuan perusahaan, tingkat pencapaian misi perusahaan, dan tingkat pencapaian pelaksanaan tugas secara aktual". Kinerja juga dapat diartikan sebagai prestasi yang dicapai perusahaan dalam suatu periode tertentu yang mencerminkan tingkat kesehatan perusahaan. Sedangakan menurut Wels, Hilton dan Gordon diterjemahkan oleh Purwatiningsih, \& Maudy Waraouw, $(2000,474)$ dalam (Achmad, 2013) menyatakan bahwa "kinerja yaitu perbandingan hasil aktual dengan sasaran dan rencana yang di anggarkan".

\section{Perputaran Aktiva Tetap}

\begin{tabular}{lllr}
\multicolumn{1}{c}{ Aktiva tetap adalah } & aktiva \\
berwujud yang dimiliki & untuk \\
digunakan dalam kegiatan & usaha \\
perusahaan, dan mempunyai & masa
\end{tabular}


manfaat lebih dari satu tahun, berupa: tanah, bangunan, peralatan,dsb. Aktiva ini berfungsi untuk mendukung menjalankan kegiatan yang dilakukan perusahaan dalam rangka memperoleh dana.

Aktiva tetap memiliki peranan penting dalam menyediakan informasi yang bermanfaat bagi kreditor dan investor. (Andari et al., 2016) Menurut (Sartono, 2016) perputaran aktiva tetap adalah rasio antara penjualan dengan aktiva tetap neto. Sedangkan menurut (Andari et al., 2016) perputaran aktiva tetap adalah posisi aktiva tetap dan taksiran waktu perputaran aktiva tetap dapat dinilai dengan menghitung tingkat perputaran aktiva tetap yaitu dengan membagi penjualan dengan total aktiva tetap bersih.

Semakin tinggi angka perputaran aktiva tetap, semakin efektif perusahaan mengelola asetnya. Rasio perputaran aktiva tetap menunjukkan sejauh mana kemampuan perusahaan menghasilkan penjualan berdasarkan aktiva tetap yang dimiliki oleh perusahaan. (Hanafi, 2016).

\section{Perputaran Persediaan}

Persediaan pada umumnya merupakan salah satu jenis aktiva lancar yang jumlahnya cukup besar dalam suatu perusahaan. Ditinjau dari segi neraca persediaan adalah barangbarang atau bahan yang masih tersisa pada tanggal neraca, atau barangbarang yang akan segera dijual, digunakan atau diproses dalam periode normal perusahaan. (Sartono, 2016).

Persediaan biasanya mencakup beberapa jenis persediaan, seperti persediaan bahan mentah, persediaan bahan setengah jadi, dan persediaan barang jadi (barang dagangan). Bahan mentah adalah bahan yang akan digunakan untuk memproduksi barang dagangan. Bahan setengah jadi adalah barang yang belum selesai sepenuhnya menjadi barang dagangan. Barang jadi adalah barang yang sudah selesai dikerjakan dan siap untuk dijual. (Hanafi, 2016)

Dengan persediaan yang cukup perusahaan dapat memenuhi pesanan dengan cepat. Namun demikian persediaan yang besar itu juga membawa konsekuensi berupa biaya yang timbul untuk mempertahankan persediaan itu. Biaya yang berkaitan dengan persediaan itu mencakup biaya pemesanan dan biaya penyimpanan dan required rate of return atas kelebihan investasi pada persediaan. Selain itu bahaya yang timbul adalah keusangan atas persediaan. Seperti halnya piutang, maka persediaan juga dapat ditingkatkan sepanjang ada penghematan bersih dengan tambahan persediaan. Keseimbangan antara penghematan dan biaya yang timbul sangat tergantung atas tambahan biaya simpan dan pengendalian persediaan yang efisien. (Sartono, 2016).

\section{Perputaran Piutang}

Piutang dagang merupakan komponen aktiva lancar yang cukup penting. Secara umum, perusahaan akan lebih suka untuk menjual dengan tunai, karena akan menerima kas lebih cepat dan memperpendek siklus kas. Tetapi tekanan persaingan membuat perusahaan bersedia menjual secara kredit. Piutang dagang muncul ketika penjualan terjadi, tetapi perusahaan belum menerima kas. Dengan demikian penggunaan piutang diharapkan bisa meningkatkan penjualan dan keuntungan, tetapi di lain pihak, piutang juga menyebabkan 
peningkatan biaya yang berkaitan dengan piutang. Biaya tersebut antara lain biaya kesempatan karena dana tertanam pada investasi piutang dan biaya piutang tidak terbayar. (Hanafi, 2016)

Kebijakan piutang yang baik adalah kebijakan yang bisa mengoptimalkan trade-off keuntungan dan risiko (kerugian) dari piutang tersebut. Semakin tinggi piutang dagang, semakin besar biaya yang berkaitan dengan piutang dagang, missal biaya investasi dan biaya piutang tidak terbayar. Tetapi semakin tinggi piutang, semakin besar tingkat penjualan yang diharapkan. Manajer keuangan harus menentukan tingkat piutang dagang yang optimal. (Hanafi, 2016).

\section{Kerangka Pemikiran}

Kinerja keuangan (Economic Performace) adalah kemampuan perusahaan dalam menjalankan setiap perencanaan kegiatan usahanya dalam mencapai keputusan investasi perusahaan yang telah direncanakan sebelumnya dalam rangka mencapai tujuan utama perusahaan.

\section{Pengaruh perputaran aktiva tetap terhadap economic performance}

Konflik kepentingan antara manajer dan pemilik perusahaan membuat pengambilan keputusan dalam pembelian aktiva tetap menjadi keputusan yang sulit. Manajer akan cenderung mengambil keputusan membeli aktiva tetap untuk kepentingan pribadinya seperti membeli mobil sebagai fasilitas. Sedangkan pemilik perusahaan cenderung mengambil keputusan untuk tidak membeli aktiva tetap, jika perusahaan terlalu banyak memiliki aktiva, maka biaya modalnya akan menjadi terlalu tinggi sehingga laba pun akan menurun. Ketika laba menurun, akan membuat dividen untuk pemegang saham menjadi berkurang. Konflik tersebut membuat investor menjadi sulit menilai kinerja perusahaan dalam mengelola asetnya secara efisien.

Menurut (Hanafi, 2016) semakin tinggi angka perputaran aktiva tetap, semakin efektif perusahaan mengelola asetnya. Rasio perputaran aktiva tetap menunjukkan sejauh mana kemampuan perusahaan menghasilkan penjualan berdasarkan aktiva tetap yang dimiliki oleh perusahaan. Berdasarkan uraian di atas, maka hipotesisnya adalah :

$\mathrm{H}_{1}$ : Perputaran aktiva tetap memiliki pengaruh terhadap economic performance.

\section{Pengaruh perputaran persediaan terhadap economic performance}

Menurut (Lestiowati, 2018) persediaan merupakan elemen penting dalam perusahaan karena pada umumnya jumlah modal kerja yang tertanam dalam persediaan cukup besar. Persediaan yang terlalu besar akan merugikan perusahaan karena akan menimbulkan penumpukan dana atau investasi yang berlebihan. Sebaliknya jumlah persediaan yang terlalu kecil di dalam gudang akan mengganggu kelancaran dan menghambat aktivitas perusahaan.

Secara umum, semakin cepat perputaran persediaan, semakin efisien dan efektif perusahaan mengelolah persediaannya untuk mencapai suatu tingkat profitabilitas tertentu yang diperoleh dari penggunaan persediaan untuk menghasilkan penjualan. (Lestiowati, 2018). Berdasarkan uraian di atas, maka hipotesisnya adalah : 
$\mathrm{H}_{2}$ : Perputaran memiliki pengaruh terhadap economic performance

Pengaruh perputaran piutang terhadap economic performance

Menurut (Lestiowati, 2018) kebijakan penjualan secara kredit merupakan salah satu upaya perusahaan untuk memperoleh penjualan yang dapat menghasilkan pendapatan bagi perusahaan. Karena adanya penjualan secara kredit ini, maka timbul piutang. Kebijakan penjualan secara kredit ini juga dapat memungkinkan perusahaan menanggung resiko kerugian sebagian akibat dari piutang yang tidak tertagih.

Semakin cepat perputaran piutang menandakan bahwa modal dapat digunakan secara efisien. (Andari et al., 2016). Berdasarkan uraian di atas, maka hipotesisnya adalah :

$\mathrm{H}_{3}$ : Perputaran piutang memiliki pengaruh terhadap economic performance

\section{METODOLOGI PENELITIAN}

Penelitian ini merupakan penelitian deskriptif kuantitatif yang menggunakan data sekunder. Objek populasi penelitian ini difokuskan pada perusahaan manufaktur yang masih listing di Bursa Efek Indonesia dengan periode pengamatan selama tahun 2014 - 2018. Pengambilan sampel dalam penelitian ini dilakukan dengan menggunakan teknik non random sampling. Salah satu teknik pengambilan sampling yang digunakan adalah metode purposive sampling.

\section{Operasional variabel}

Untuk

mempermudah memahami variabel-variabel yang digunakan oleh peneliti dalam penelitian ini, maka dapat dilihat dalam tabel berikut ini:

Tabel 1

Pengukuran Variabel

\begin{tabular}{|c|c|c|c|}
\hline Variabel & Indikator & Rumus & Skala \\
\hline Dependen & Return on Assets & 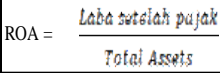 & Rasio \\
\hline \multirow{3}{*}{ Independen } & $\begin{array}{c}\text { Peputaran Aktiva } \\
\text { Tetap }\end{array}$ & FATO Penfuctan & Rasio \\
\hline & $\begin{array}{l}\text { Perputaran } \\
\text { Persediaan }\end{array}$ & 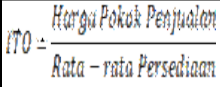 & Rasio \\
\hline & Perputaran Piutang & 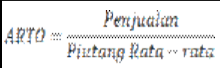 & Rasio \\
\hline
\end{tabular}

\section{Analisis Regresi}

Metode analisis yang digunakan adalah metode analsis kuantitatif yaitu untuk menganalisis informasi kuantitatif (dapat diukur, diuji dan ditransformasikan dalam bentuk persamaan, tabel dan sebagainya). Model analsis yang digunakan adalah model regresi data panel.

\section{Teknik Penaksiran Model}

Sriyana (2014:81)

hal terpenting dalam melakukan analisis regresi data panel adalah pemilihan metode estimasi yang digunakan. Sejauh ini terdapat tiga model pendekatan estimasi yang biasa digunakan pada regresi data panel, yaitu pendekatan dengan model common effects, fixed effects, dan random effects.

\section{Common Effect Model}

Merupakan pendekatan model data panel yang paling sederhana karena hanya mengkombinasikan data time series dan cross section. Pada model ini tidak diperhatikan dimensi waktu maupun individu, sehingga diasumsikan bahwa perilaku data perusahaan sama dalam berbagai kurun waktu. Metode ini bisa menggunakan pendekatan Ordinary 
Least Square (OLS) atau teknik kuadrat terkecil untuk mengestimasi model data panel. (Hidayat, 2014)

\section{Fixed Effect Model}

Model ini mengasumsikan bahwa perbedaan antar individu dapat diakomodasi dari perbedaan intersepnya. Untuk mengestimasi data panel model Fixed Effects menggunakan teknik variabel dummy untuk menangkap perbedaan intersep antar perusahaan, perbedaan intersep bisa terjadi karena perbedaan budaya kerja, manajerial, dan insentif. Namun demikian slopnya sama antar perusahaan. Model estimasi ini sering juga disebut dengan teknik Least Squares Dummy Variable (LSDV). (Hidayat, 2014)

\section{Random Effect Model}

Model ini akan mengestimasi data panel dimana variabel gangguan mungkin saling berhubungan antar waktu dan antar individu. Pada model Random Effect perbedaan intersep diakomodasi oleh error terms masing-masing perusahaan. Keuntungan menggunakan model Random Effect yakni menghilangkan heteroskedastisitas. Model ini juga disebut dengan Error Component Model (ECM) atau teknik Generalized Least Square (GLS). (Hidayat, 2014)

\section{HASIL PENELITIAN DAN PEMBAHASAN \\ Deskripsi Objek Penelitian}

Dalam penelitian ini, data penelitian diperoleh dari perusahaanperusahaan manufaktur yang terdaftar di Bursa Efek Indonesia 2014-2018 Data yang digunakan berasal dari laporan keuangan tahunan yang dipublikasikan perusahaan dari tahun 2014-2018

\section{Analisis Data}

Analisis Statistik Deskriptif

Sebelum melakukan pengujian secara keseluruhan pengaruh antara variabel perputaran aktiva tetap, perputaran persediaan, dan perputaran piutang terhadap economics performance. Terlebih dahulu, akan ditinjau mengenai deskripsi variabel penelitian dengan analisis statistik deskriptif. Uji statistik deskriptif digunakan untuk mengidentifikasi variabel economics performance, perputaran aktiva tetap, perputaran persediaan, dan perputaran piutang yang dapat dilihat pada tabel berikut ini :

Tabel 2

Hasil Uji Statistik Deskriptif

\begin{tabular}{|l|c|c|c|c|}
\hline & ROA & FATO & ARTO & ITO \\
\hline Mean & 0.098857 & 4.287048 & 10.13605 & 5.069429 \\
\hline Median & 0.080000 & 3.860000 & 7.105000 & 4.620000 \\
\hline Maximum & 0.530000 & 16.01000 & 78.74000 & 26.00000 \\
\hline Minimum & 0.000000 & 0.390000 & 2.050000 & 1.120000 \\
\hline Std. Dev. & 0.092248 & 2.922759 & 10.18611 & 3.723322 \\
\hline Skewness & 2.094990 & 1.633857 & 3.589115 & 3.276313 \\
\hline Kurtos is & 8.134878 & 6.196927 & 18.95254 & 17.70899 \\
\hline & & & & \\
\hline Jarque-Bera & 384.3254 & 182.8601 & 2677.591 & 2268.799 \\
\hline & & & & \\
\hline Probability & 0.000000 & 0.000000 & 0.000000 & 0.000000 \\
\hline & & & & \\
\hline \multicolumn{1}{|c|}{ Sum } & 20.76000 & 900.2800 & 2128.570 & 1064.580 \\
\hline Sum Sq. Dev. & 1.778526 & 1785.386 & 21685.17 & 2897.394 \\
\hline & & & & \\
\hline Observations & 210 & 210 & 210 & \multirow{2}{*}{210} \\
\hline & & & & \\
\hline
\end{tabular}

Sumber : Hasil Pengolahan Data Eviews 9.0

Berdasarkan hasil uji statistik deskriptif dari 210 sampel data perusahaan yang diobservasi, maka dapat disimpulkan Economic performance (ROA) memiliki nilai minimum sebesar 0,00 dan nilai maksimum sebesar 0.53. Nilai mean sebesar 0,098857 dengan standar deviasi sebesar 0,092248. Perputaran aktiva tetap (FATO) memiliki nilai minimum sebesar 0,39 dan nilai maksimum sebesar 16,01 . Nilai rata- 
rata sebesar 4,287048 dengan standar deviasi sebesar 2,922759. Perputaran piutang (ARTO) memiliki nilai minimum sebesar 2,05 dan nilai maksimum sebesar 78,74. Nilai ratarata sebesar 10,13605 dengan standar deviasi sebesar 10,18611. Perputaran persediaan (ITO) memiliki nilai minimum sebesar 1,12 dan nilai maksimum sebesar 26,00. Nilai ratarata sebesar 5,069429 dengan standar deviasi sebesar 3,723322.

\section{Kesimpulan Model}

Berdasarkan pengujian terhadap tiga model regresi data panel, dapat disimpulkan bahwa model fixed effect dalam regresi data panel digunakan lebih lanjut dalam mengestimasi pengaruh perputaran aktiva tetap, perputaran persediaan, dan perputaran piutang terhadap economic performance.

Tabel 3

Kesimpulan Model

\begin{tabular}{|l|c|c|}
\hline \multicolumn{1}{|c|}{ Metode } & Pengujian & Hasil \\
\hline Uji Chow & CEM vs FEM & FEM \\
\hline Uji Hausman & FEM vs REM & REM \\
\hline Uji Lagrange Multiplier & CEM vs REM & REM \\
\hline
\end{tabular}

Sumber : data diolah (2019)

\section{Uji Hipotesis}

\section{Uji F}

Menurut Eksandy dan Herianto (2017) hasil uji F menjelaskan apakah semua variabel bebas yang dimasukkan ke dalam model secara simultan atau bersama-sama mempunyai pengaruh terhadap variabel terikat atau dengan kata lain model fit atau tidak. Apabila uji $\mathrm{F}$ tidak berpengaruh maka penelitian ini tidak layak untuk dilanjutkan. Berikut ini adalah hasil uji F yaitu :
Tabel 4

Hasil Uji F

\begin{tabular}{|c|c|c|c|}
\hline \multicolumn{4}{|c|}{ Wieighted Statistics } \\
\hline R.squared & 0071326 & Mean dependentvar & 0017818 \\
\hline Adusted R.squared & 0.057801 & S.D. dependent var & 0.035568 \\
\hline S.E. of regresssion & 0.034525 & Sum squarêd ressid & 0.245543 \\
\hline F-sta stic & 5.273866 & Durbin-wistson stat & 1.571890 \\
\hline Prosif-statistic; & 0.001592 & & \\
\hline
\end{tabular}

Sumber : Hasil Pengolahan Data Eviews 9.0

Pada tabel 4.3 menunjukkan bahwa nilai $F$-statistic sebesar 5.273866, sementara F Tabel dengan tingkat $\alpha=5 \%$, df $1(\mathrm{k}-1)=3$ dan df2(n-k) $=206$ didapat nilai $F$ Tabel sebesar 2,648432. Dengan demikian F-statistic (5.273866) > F Tabel $(2,648432)$ dan nilai Prob(F-statistic) $0,001592<0,05$ maka dapat disimpulkan bahwa Ha diterima, maka dengan demikian dapat disimpulkan bahwa variabel-variabel independen dalam penelitian ini yang terdiri dari perputaran aktiva tetap, perputaran piutang, dan perputaran persediaan secara bersama-sama berpengaruh terhadap economic performance.

\section{Uji Adjusted $\mathbf{R}^{2} \quad$ (Koefisien Determinasi)}

\section{Tabel 5}

Hasil Uji R ${ }^{2}$ (Koefisien Determinasi)

\begin{tabular}{|c|c|c|}
\hline \multicolumn{3}{|c|}{ weighted Statistics } \\
\hline R-squared & 0.071326 lilean dependentivar & 0.017818 \\
\hline Adjusted R-squared & 0.057801 S.D. dependentwar & 0.035568 \\
\hline S.E. of regression & 0.034525 Sum squared resid & 0.245543 \\
\hline F-statistic & 5.273866 Durbin-ritiatson stat & 1.571890 \\
\hline Prob(F-statistic: & 0.001592 & \\
\hline
\end{tabular}

Sumber : Hasil Pengolahan Data Eviews 9.0

Pada tabel menunjukkan bahwa nilai Adjusted $R$-squared sebesar 0,071326, artinya bahwa kemampuan seluruh variabel bebas yaitu 
perputaran aktiva tetap, perputaran piutang, dan perputaran persediaan dalam menjelaskan variabel terikat economic performance yaitu $5,78 \%$. Sementara sisanya 94,22\% dijelaskan variabel lain yang tidak termasuk dalam penelitian ini.

\section{Uji t}

Tabel 6

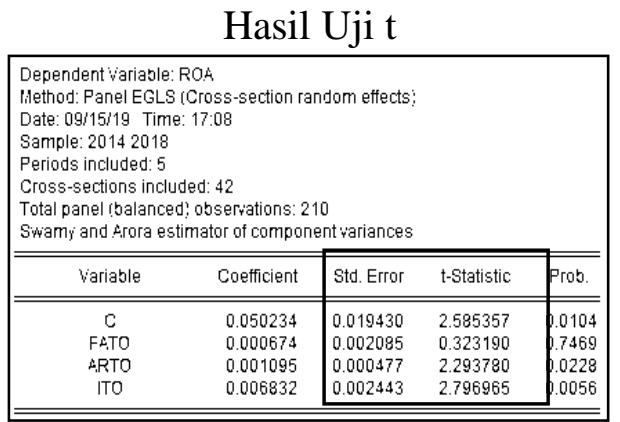

Sumber : Hasil Pengolahan Data Eviews 9.0

Pada tabel dapat disimpulkan bahwa :

\section{Persamaan Model Regresi Data Panel}

Berdasarkan hasil pemilihan model regresi data panel yang dilakukan maka persamaan model regresi yang diperoleh adalah sebagai berikut :

$$
\begin{gathered}
\mathrm{Y}=0,050234+0,000674 \text { FATO + } \\
0,001095 \text { ARTO +0,006832 ITO + e }
\end{gathered}
$$

\section{Interpretasi Hasil}

Penelitian ini bertujuan untuk mengetahui pengaruh pengaruh perputaran aktiva tetap, perputaran piutang, dan perputaran persediaan secara simultan dan parsial terhadap economic performance pada perusahaan manufaktur periode penelitian selama 2014-2018. Rangkuman dari hasil pengujian yaitu

Pengaruh perputaran aktiva tetap terhadap economic performance

Nilai $t$-statistic perputaran aktiva tetap (ROA) sebesar 0,323190, sementara $\mathrm{t}$ tabel dengan tingkat $\alpha=$ $5 \%$, df $(\mathrm{n}-\mathrm{k})=206$ didapat nilai $\mathrm{t}$ tabel sebesar 1,97. Dengan demikian $t$-statistic perputaran aktiva tetap $(0,323190)<\mathrm{t}$ tabel $(1,97)$ dan dan nilai Prob 0,7469 > 0,05 maka dapat disimpulkan bahwa variabel perputaran aktiva tetap dalam penelitian ini secara parsial tidak memiliki pengaruh terhadap economic performance.

Hasil penelitian ini sejalan dengan penelitian (Andari, Arifati, \& Andini, 2016) yang membuktikan bahwa tidak terdapat pengaruh signifikansi antara perputaran aktiva terhadap economic performance yang menggunakan analisis rasio keuangan profitabilitas (ROA). Secara teori jika perusahaan terlalu banyak memiliki aktiva, maka biaya modalnya akan menjadi terlalu tinggi sehingga laba pun akan menurun dan economic performance perusahaan akan menurun juga. Semakin tinggi angka perputaran aktiva tetap, semakin efektif perusahaan mengelola asetnya. Hasil penelitian ini berarti tidak sesuai dengan teori yang ada bahwa perputaran aktiva tetap dapat mempengaruhi economic performance. Tidak berpengaruhnya perputaran aktiva tetap terhadap economic performance ini karena jumlah aktiva tetap yang dimiliki oleh perusahaan manufaktur yang terdaftar di Bursa Efek Indonesia tahun 20142018 rata-rata hanya $34 \%$ dari total aktiva, sehingga biaya modal atas aktiva tetap yang timbul tidak banyak dan tidak terlalu mempengaruhi laba perusahaan. Hasil penelitian ini tidak mendukung penelitian (Achmad, 2013) dan (Rahmi, n.d.) yang membuktikan adanya pengaruh signifikan perputaran aktiva tetap terhadap economic performance. 
Pengaruh perputaran persediaan terhadap economic performance

Nilai $t$-statistic perputaran persediaan (ITO) sebesar 2,796965, sementara $\mathrm{t}$ tabel dengan tingkat $\alpha=$ $5 \%$, df $(\mathrm{n}-\mathrm{k})=206$ didapat nilai $\mathrm{t}$ tabel sebesar 1,97. Dengan demikian $t$-statistic perputaran persediaan $(2,796965)>\mathrm{t}$ tabel $(1,97)$ dan dan nilai Prob 0,0056 < 0,05 maka dapat disimpulkan bahwa variabel perputaran persediaan dalam penelitian ini secara parsial berpengaruh terhadap economic performance.

Hasil penelitian ini sejalan dengan (Rahayu Eka Ayu \& Susilowibowo Joni, 2014), (Suminar, 2013), dan (Lestiowati, 2018) yang membuktikan bahwa perputaran persediaan secara parsial berpengaruh positif terhadap economic performance yang menggunakan proksi return on assets (ROA).

Berpengaruhnya perputaran persediaan terhadap economic performance dikarenakan pada era globalisasi saat ini hampir semua perusahaan manufaktur telah menerapkan konsep Enterprise Resource Planning (ERP) yang merupakan konsep untuk merencanakan dan mengelola sumber daya perusahaan, yaitu berupa paket aplikasi program terintegrasi dan multi modul yang dirancang untuk melayani dan mendukung berbagai fungsi dalam perusahaan. Sehingga pengelolaan persediaan menjadi lebih efisien dan mengurangi biaya-biaya, seperti biaya penyimpanan (biaya gudang), pengamanan, asuransi, dan pajak properti serta beban-beban terkait lainnya. Pengurangan biayabiaya ini akan meningkatkan laba perusahaan sekaligus economic performance perusahaan.
Hasil penelitian ini tidak sejalan dengan (Suprihatin \& Nasser, 2016) dan (Rahmi, n.d.) yang membuktikan bahwa perputaran persediaan tidak memiliki pengaruh terhadap economic performance.

\section{Pengaruh perputaran piutang terhadap economic performance \\ Nilai t-statistic perputaran} piutang (ARTO) sebesar 2,293780, sementara $\mathrm{t}$ tabel dengan tingkat $\alpha=$ $5 \%$, df $(\mathrm{n}-\mathrm{k})=206$ didapat nilai $\mathrm{t}$ tabel sebesar 1,97. Dengan demikian $t$-statistic perputaran piutang $(2,293780)>\mathrm{t}$ tabel $(1,97)$ dan dan nilai Prob 0,0228 < 0,05 maka dapat disimpulkan bahwa variabel perputaran piutang dalam penelitian ini secara parsial berpengaruh terhadap economic performance.

Hasil penelitian ini sejalan dengan (Andari et al., 2016) dan (Suminar, 2013) yang membuktikan bahwa perputaran piutang berpengaruh positif terhadap economic performance yang menggunakan proksi return on assets (ROA).

Secara teori kebijakan penjualan secara kredit dapat meningkatkan penjualan perusahaan, tetapi memungkinkan perusahaan menanggung resiko kerugian sebagai akibat dari piutang yang tidak tertagih, sehingga piutang harus dikelola secara efisien untuk meningkatkan economic performance perusahaan. Semakin cepat perputaran piutang menandakan bahwa piutang lancar sehingga tingkat pengembalian terhadap pendapatan meningkat dan economic performance juga meningkat.

Berpengaruhnya perputaran piutang dikarenakan manajemen kebijakan penjualan kredit yang telah dibuat standar kredit seperti kualitas 
piutang yang dapat diterima, jangka waktu periode kredit, potongan tunai untuk pembayaran lebih cepat, dan program pengumpulan piutang. Sehingga kemungkinan terjadinya beban piutang tak tertagih lebih sedikit dan tidak terlalu mempengaruhi laba perusahaan sekaligus economic performance.

Hasil ini tidak sejalan dengan (Lestiowati, 2018) dan (Rahayu Eka Ayu \& Susilowibowo Joni, 2014) yang membuktikan tidak ada pengaruh antara perputaran piutang terhadap economic performance.

\section{KESIMPULAN \\ Kesimpulan}

Perputaran aktiva tetap tidak berpengaruh terhadap economic performance. Hal ini terbukti pada hasil pengujian variabel pertama menunjukkan perputaran aktiva tetap secara parsial tidak berpengaruh terhadap economic performance dengan nilai $t$-statistic sebesar $0,323190<\mathrm{t}$ tabel 1,97 dengan tingkat Prob sebesar 0.7469 atau lebih besar dari 0,05 sehingga hipotesis pertama ditolak. Dengan demikian maka dapat disimpulkan bahwa bagaimana pun hasil perputaran aktiva tetap tidak mempengaruhi nilai economic performance.

$$
\text { Perputaran persediaan }
$$

berpengaruh terhadap economic performance. Hal ini terbukti pada hasil pengujian variabel kedua menunjukkan perputaran persediaan secara parsial berpengaruh terhadap economic performance dengan nilai $t$ statistic sebesar 2,796965 > t tabel 1,97 dengan tingkat Prob sebesar 0.0056 atau lebih kecil dari 0,05 sehingga hipotesis pertama diterima. Dengan demikian maka dapat disimpulkan bahwa naik atau turunnya nilai perputaran persediaan mempengaruhi nilai economic performance.

Perputaran piutang berpengaruh terhadap economic performance. Hal ini terbukti pada hasil pengujian variabel ketiga menunjukkan perputaran piutang secara parsial berpengaruh terhadap economic performance dengan nilai $t$-statistic sebesar 2,293780 > t tabel 1,97 dengan tingkat Prob sebesar 0.0228 atau lebih kecil dari 0,05 sehingga hipotesis pertama diterima. Artinya maka dapat disimpulkan bahwa naik atau turunnya nilai perputaran piutang mempengaruhi nilai economic performance.

\section{DAFTAR PUSTAKA}

Achmad, N. Dan L. H. (2013). Pengaruh Manajemen Aset Terhadap Kinerja Keuangan Perusahaan. Jurnal Ilmiah Manajemen Kesatuan, 1(1), 2338.

Andari, Y., Arifati, R., \& Andini, R. (2016). Pengaruh Perputaran Barang Jadi, Arus Kas,Piutang Dan Aktiva Tetap Terhadap Profitabilitas Pada Perusahaan Perdagangan Eceran Yang Terdaftar Di Bei Periode 20092014. Journal Of Accounting, 2(2), 1-9.

Eksandy, A., \& Heriyanto, F. (2017). Metode Penelitian Akuntansi Dan Keuangan. Tangerang: Universitas Muhammadiyah Tangerang.

Hanafi, M. M. (2016). Manajemen Keuangan (2nd Ed.). Yogyakarta: Bpfe-Yogyakarta.

Hidayat, A. (2014). Penjelasan 
Metode Analisis Regresi Data

Panel. Retrieved From

Https:/Www.Statistikian.Com/

2014/11/Regresi-Data-

Panel.Html/Amp

Lestiowati, R. (2018). Analisis Perputaran Persediaandan

Perputaran Piutang Terhadap

Profitabilitas (Studi Empiris

Pada Perusahaan Sektor

Makanan Danminuman Yang

Terdaftar Di Bursa Efek

Indonesia Tahun 2014-2016).

Jurnal Akuntansi, 6(1), 25-39.

Https://Doi.Org/10.24964/Ja.V6

i1.562

Mustoffa, A. F. (2014). Pengukuran

Kinerja Keuangan Dengan

Pendekatan Economic (Eva)

Dan (Mva). 13(02), 61-69.

Rahayu Eka Ayu, \& Susilowibowo Joni. (2014). Pengaruh

Perputaran Kas, Perputaran

Piutang Dan Perputaran

Persediaan Terhadap

Profitabilitas Perusahaan

Manufaktur. Jurnal Ilmu

Manajemen, 2. Retrieved From

Https://Www.Mendeley.Com/C

atalogue/Eka-Ayu-Rahayu-

Dan-Joni-Susilowibowo-

Pengaruh-Perputaran-Kas/

Rahmi, D. J. (N.D.). Pengaruh Perputaran Aktiva Tetap, Perputaran Persediaan, Perputaran Piutang Terhadap Profitabilitas Pada Perusahaan Real Estate Dan Property Yang Listing Di Bei. Universitas Riau.

Sarita, B., Takdir, D. S., Sujono, \& Sabrin. (2016). The Effect Of Profitability On Firm Value In Manufacturing Company At Indonesia Stock Exchange. The International Journal Of Engineering And Science, 5(10), 2319-1813.
Https://Doi.Org/10.1016/00144827(80)90264-5

Sartono, R. A. (2016). Manajemen Keuangan: Teori Dan Aplikasi (4th Ed.). Yogyakarta: BpfeYogyakarta.

Suminar, M. T. (2013). Industri Barang Konsumsi Yang Terdaftar. 1-19.

Suprihatin, N., \& Nasser, E. (2016).

Pengaruh Perputaran Kas,

Perputaran Piutang Usaha,

Perputaran Persediaan Dan

Leverage Terhadap Kinerja

Keuangan Perusahaan. Jurnal

Akuntansi, 3(2), 66-83.

Retrieved From

Https://Www.Google.Com/Url?

$\mathrm{Sa}=\mathrm{T} \& \mathrm{Rct}=\mathrm{J} \& \mathrm{Q}=\& \mathrm{Esrc}=\mathrm{S} \&$ So

urce $=$ Web $\& \mathrm{Cd}=1 \& \mathrm{Cad}=\mathrm{Rja} \&$

Uact $=8 \&$ Ved=2ahukewjt_Thch

khfahujty 8 khvyddquqfjaaegqiar ab\&Url=Http $\% 3 \mathrm{a} \% 2 \mathrm{f} \% 2 \mathrm{fe}-$

Jurnal.Lppmunsera.Org\%2finde x.Php $\% 2$ fakuntansi $\% 2$ farticle $\%$

2fview\%2f210\&Usg=Aovvaw3 nvo-Y3jq3aiz6xhe1aoak

Winata, V. S., Yuniarta, G. A., \& Sinarwati, N. K. (2016). Perusahaan Dengan Pendekatan Economic Value Added ( Eva ) Dan Market Value Added ( Mva ) Pada Perusahaan Manufaktur Yang Go Public Di Bursa Efek Indonesia Tahun 2012-2015. E-Journal S1 Ak Universitas Pendidikan Ganesha, 6(3). 